\title{
Susceptibility of Common Bean (Phaseolus Vulgaris L) Cultivars Grown in Menoua Division, West Region of Cameroon to Storage Fungi Pathogens
}

\author{
Teh Exodus Akwa ${ }^{1 *}$, John M Maingi ${ }^{1}$ and Jonah Birgen ${ }^{2}$ \\ ${ }^{1}$ Department of Biochemistry, Microbiology and Biotechnology, Kenyatta University, Kenya \\ ${ }^{2}$ Department of Plant Sciences, Kenyatta University, Kenya
}

\begin{abstract}
In Menoua Division, common bean (Phaseolus vulgaris L.) is amongst the legumes which are greatly cultivated with farmers growing different cultivar types. Upon harvest, these cultivars are stored to be used as food over the storage period or for sale. Unfortunately, appropriate facilities for storing the cultivars after harvest are not available hence predisposing the grains to fungi infection. The knowledge of cultivars resistant to damage by storage fungi would therefore have a considerable value in the absence of appropriate storage structures. This research aimed at determining whether differences might exist among common bean cultivars in susceptibility to damage by fungi under storage environment by farmers in Menoua Division and also identifying the less susceptible cultivar type to fungi infection. Six different common bean cultivars were evaluated for fungi contamination upon storage using PDA media. The large seeded bean cultivar was designated the most susceptible to fungi infection on storage having the significantly highest $(P<0.05)$ fungi population. The least susceptible were the pinto bean cultivar, navy bean cultivar and Pea bean cultivar. Four storage fungal genera were isolated from the different bean cultivars. These included: Aspergillus, Fusarium, Penicillium, Morphospecies or 'Mycelia sterilia'. Inherent differences exist among cultivars of common bean in susceptibility to infection and damage by storage fungi.
\end{abstract}

\section{Keywords}

Susceptibility, Identification, Significance difference, Phaseolus Vulgaris $L$

\section{Abbreviations}

PDA: Potato Dextrose Agar; ANOVA: Analysis of variance

\section{Introduction}

Common bean (Phaseolus vulgaris L.) is a major and essential legume utilized by at least 300 million people, cultivated greatly in the developing countries [1]. Common bean, a crop that grows annually and best under warm climatic conditions at a temperature range of $18{ }^{\circ} \mathrm{C}$ to $24{ }^{\circ} \mathrm{C}$ is classified under the family Fabaceae [2]. Its first cultivation was done about 8000-years ago in Peru and Mexico and presently it is cultivated worldwide [3]. It is one of the most produced and consumed crop in Africa [4]. Annually, an estimate of about 4 million hectares of land is used in the cultivation of common bean in Africa leading to an improvement of protein content in diet of millions of inhabitants in rural and urban communities [5].

In Cameroon, based on legume consumption, common bean is classified third after groundnut and cowpea [6]. In the Western parts of Cameroon, the high nutrients value derived from common bean coupled to its ability to survive and grow even during changes in climates makes it the most important legume being cultivated [7]. The beneficial effects of common bean have led to a significant increase in its demand both within Cameroon and from buyers from other countries which are neighboring to Cameroon [8]. The biggest common bean producing zones in Cameroon include the Western Highlands with a national production of at least $90 \%$ [9].

*Corresponding author: Teh Exodus Akwa, Department of Biochemistry, Microbiology and Biotechnology, Kenyatta University, Nairobi, Kenya, P.O BOX 43844-00100-NAIROBI, Tel: +254792-775729

Accepted: August 18, 2020

Published online: August 20, 2020

Citation: Akwa TE, Maingi JM, Birgen J (2020) Susceptibility of Common Bean (Phaseolus Vulgaris L) Cultivars Grown in Menoua Division, West Region of Cameroon to Storage Fungi Pathogens. J Hortic Sci Res 3(1):94-103 

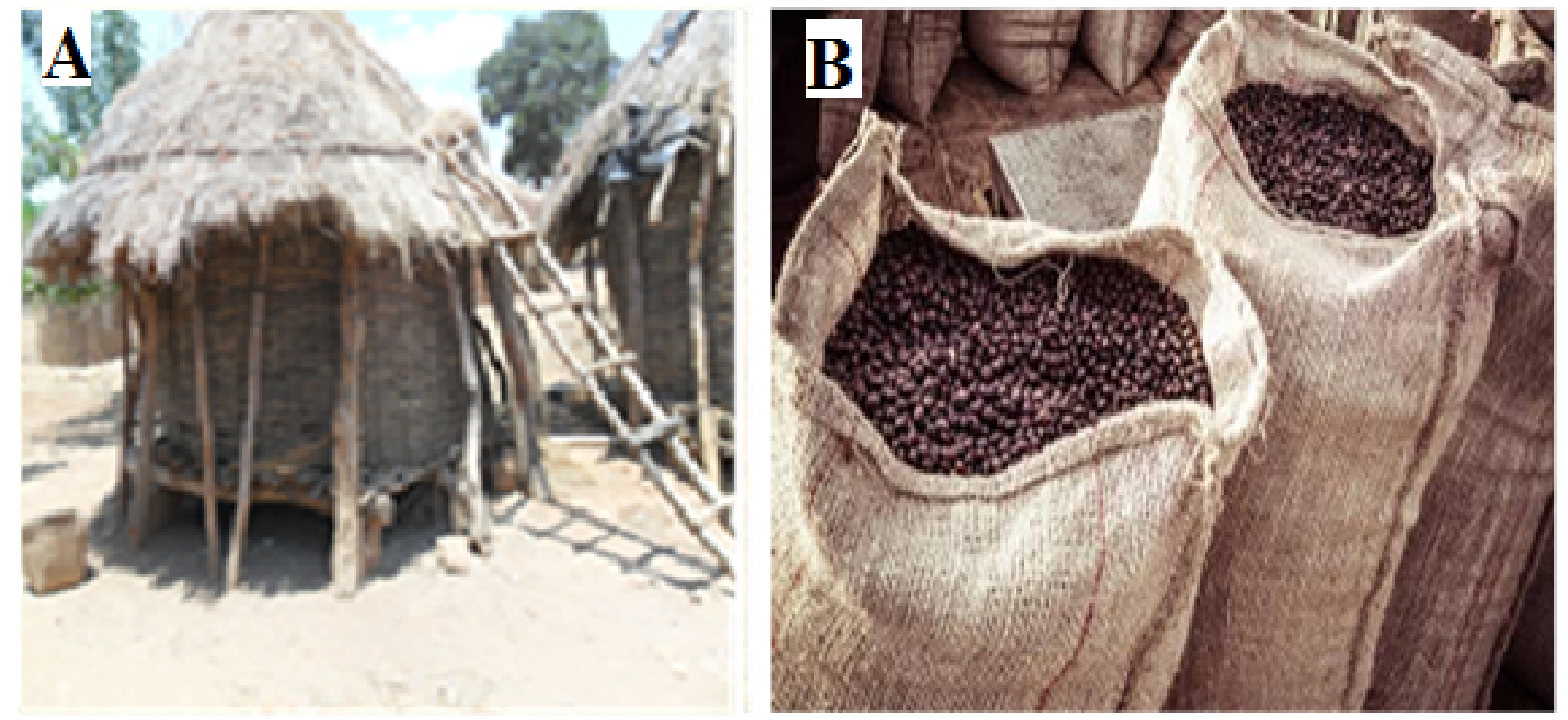

Figure 1: Storage structures used by farmers in the Menoua Division (a) Grass line barns; (b) Gunny bags.

Farmers in Cameroon after harvest store common bean in bags (Figure 1B) while others store in grass line barns (Figure $1 \mathrm{~A})$ referred locally to as 'banda'. Newer and improved techniques have been introduced in handling and storing grains after harvest but these techniques have not been applicable by local farmers either due to their expensive nature to operate or the farmers are reluctant to introduce new changes. The size of the storage structure used by farmers depends on the size of their farm lands. Farmers who cultivate in large scale built large barns for long term storage which can last for an average period of 7 months while those who practice small scale farming use gunny bags to store their produce.

The storage structure in (Figure $1 A$ ) is a grass lined wall and a grass thatched roof. In (Figure 1B) the store for common bean is a structure that is made of fibre. In these structures the bean gets exposed to elements that bring about infection of fungi. Some of these predisposing elements include; water from leaking roofs which increases the moisture content of the bean creating a hotspot for the growth of fungi leading to infection of the grains. Infestation by insects such as weevils brings about holes on the grains thereby becoming an avenue through which fungi infect the grains. These storage structures can also be prone to attack by small mammals such as rats, squirrels and mice which can damage the bean by nibbling and in addition deposit their droppings and urine which encourages the growth of fungi. Fungi infection on the stored bean leads to deterioration in quality (colour, taste, flavour) and quantity (reduction in the amount which can be useful). However, it is possible that the incidence and severity of fungi infection vary with different common bean cultivars over the storage period. This research aimed at identifying the common bean cultivar type which is less susceptible to fungal infection under storage environment by farmers in Menoua Division. The outcome of this study will help recommend common bean farmers and agriculturalist on the best cultivar type to be stored under long periods.

\section{Materials and Methods}

\section{The study site}

Cameroon is located in the central part of Africa (Figure 2A) [10]. It is comprised of ten regions. The West region of Cameroon (Figure 2B) [10] is the smallest in size in all of these ten regions but highest in population density. As of 2015 this region had a population of 1,2921,590 inhabitants [11]. The West region is made up of 8 divisions, Menoua Division included. Six subdivisions constitute the Menoua Division. These sub divisions include: Dschang, Fokoue, Fongo-Tongo, Nkong-Ni, Penka-Michel and Santchou (Figure 2C) [10]. A total of 22 villages arise from these sub-divisions.

The Menoua division covers an area of about $1380 \mathrm{~km}^{2}$ and has Dschang as its capital [12]. The Menoua division spans across santchou which is at an attitude of $610 \mathrm{~m}$ to the sub division Nkong-Ni at an attitude of $2100 \mathrm{~m}$ [13]. Most parts of the region are characterized by tropically cold climatic conditions. The Menoua Division has two seasons; the rain and dry seasons. The rainy periods commence in April and end in September while the dry season begins from October to March. As of 2006 to 2011, the annual temperature value recorded in this region ranged between $25.35^{\circ} \mathrm{C}$ to $13.66^{\circ} \mathrm{C}$ and a rainfall of about $1717.70 \mathrm{~mm}$ [13]. The main activities practiced in the Menoua Division are agronomy and agriculture [14]. A population of about $80 \%$ of inhabitants in the Menoua division practice farming with major crops such as irish potatoes, maize and common bean [15]. Farmers in the Menoua division grow common bean twice a year. The first cultivation begins in March and the second begins in August. Main production of common bean occurs in late rainy season (August) so that maturity coincides with dry weather (October to November). During the early rains, the production of common bean is less. This is because the bean will mature during heavy rains with attendant challenges of drying. 


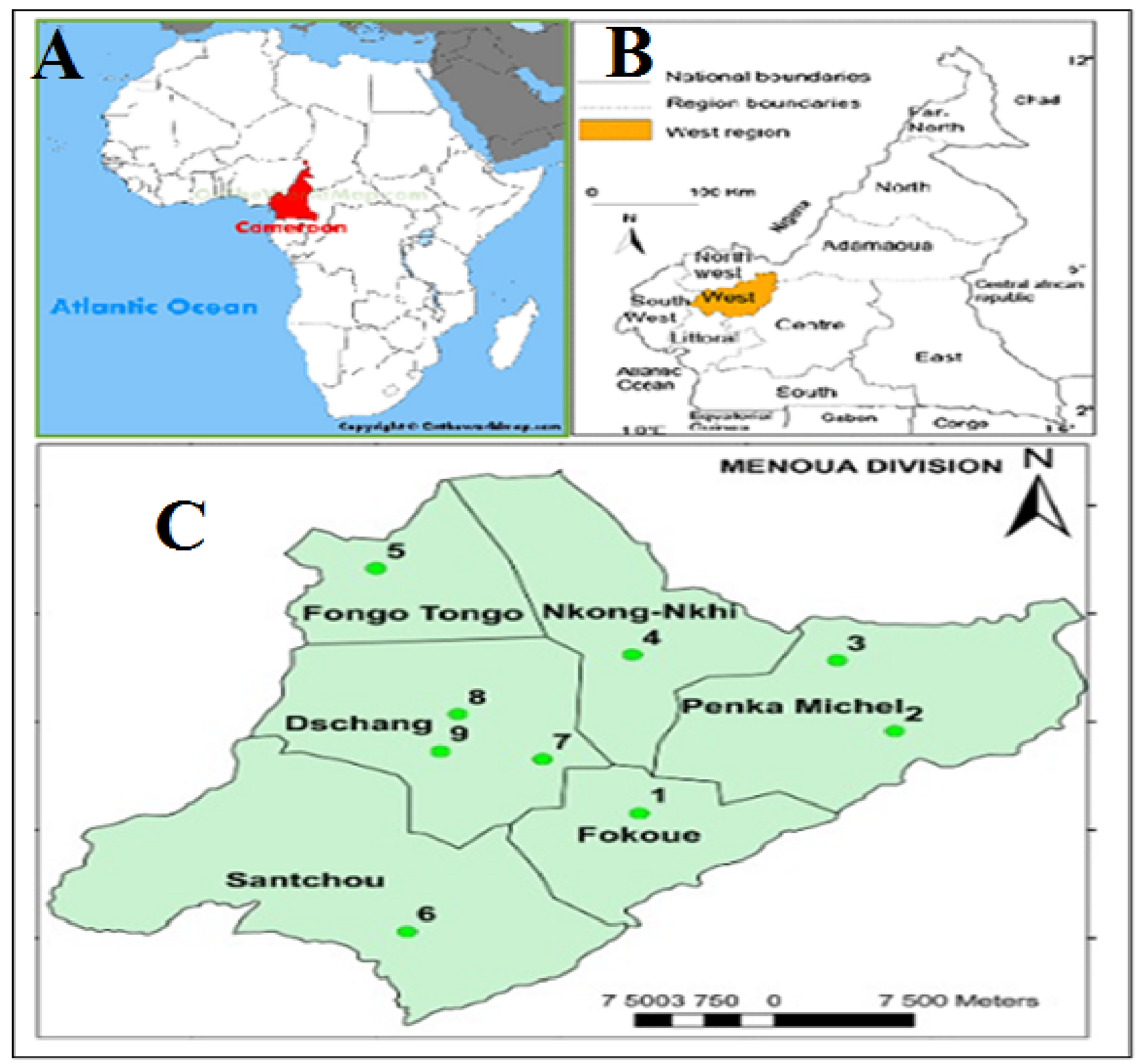

Figure 2: Location of Study Area (a) Location of Cameroon in Africa; (b) Location of the West Region in Cameroon; (c) Sub-Divisions found in the Menoua Division.

\section{The study design}

The study took place in the Menoua Division, West Region of Cameroon between April 2019 - May 2019 during the rainy season, with mean climatic temperatures varying between $19.7^{\circ} \mathrm{C}$ to $26.0^{\circ} \mathrm{C}$. The design used in the field was a split plot design [16] with Sub Divisions in the Menoua Division as the main plot and common bean cultivars as sub-plots. The research employed a combination of quantitative and qualitative approach. A multi-stage sampling was used to select participants in ways that ensured representativeness of the target population. At the first stage, zones/sub-divisions in the Menoua division where common bean was cultivated, consumed and equally stored several months after harvest were selected. This selection was done based on geographical evidence in common bean farming. The sampled subdivisions were: Dschang, Santchou, NkongNkhi, Fokoue, Penka Michel and FongoTongo.

\section{Sampling of farmers and collection of common bean samples}

Major common bean cultivating farmers and the cultivars they grow from these Sub-divisions in the Menoua Division were first identified through the divisional delegation of agriculture and rural development in the Menoua Division.

The Yamane, et al. [17] Formula was used to obtain the sample size of farmers.

This was given as:

$$
n=\frac{N}{[1+N(e)]^{2}}
$$


Citation: Akwa TE, Maingi JM, Birgen J (2020) Susceptibility of Common Bean (Phaseolus Vulgaris L) Cultivars Grown in Menoua Division, West Region of Cameroon to Storage Fungi Pathogens. J Hortic Sci Res 3(1):94-103

Where, $\mathrm{n}$ represents sample size, $\mathrm{N}$ represents size of the population, e is precision level or sampling error (5\%).

A population size $(\mathrm{N})$ of 42 farmers obtained from archives from the Divisional delegation of agriculture and rural development was used in the determination of the sample size. The sample size for the farmers was calculated as illustrated below:

$$
\begin{aligned}
& \mathrm{N}=42 \text { farmers, } \mathrm{e}=0.05 \\
& \text { Substituting gives } n=\frac{42}{1+42(0.05)^{2}}=38 \text { farmers }
\end{aligned}
$$

A total of 38 common bean cultivating farmers were sampled from the various sub divisions that constituted the Menoua division. The farmers were distributed as follows: 11 from Dschang, 9 from Santchou, 4 from Fokoue, 3 from Fongotongo, 5 from Penka Michel and 6 from Nkong-Nkhi. Their cultivars were sampled. Stored bean cultivars were collected from their storage structures (gunny bags). These cultivars were collected from storage structures after being stored for 3 months after harvest. Sampling was carried out by picking the common bean grains multiple times from these same storage bags using bowls. The samples were then mixed to form one homogenous sample that was then labeled appropriately.

A total of 500 grams of each common bean cultivar was collected. Six different types of common bean cultivars were collected namely: Kidney bean (small red), Black turtle bean (black bean), Navy bean (white bean), Pinto bean (mottled brown bean), Pea bean (mottled red bean) and Large seeded bean (Large red). These cultivars (Figure 3) were placed in sterile polyethene bags and labeled for easy identification.

\section{Detection and isolation of fungi from stored common bean cultivars grown in the menoua di- vision}

All stored common bean samples collected from the subdivisions were brought to the University of Buea Plant Science Laboratory, Cameroon for fungi isolation. Specific sterilization protocol [18] was used for the maximum recovery of fungi. Five replicates of 50 common bean grains of each cultivar type per treatment were immersed in 70\% ethanol for $1 \mathrm{~min}$ ute. Surface sterilization of the grains was done using $10 \%$ sodium hypochlorite solution for 1 minute. Finally, the grains were rinsed with distilled water for 3 minutes. The common bean grains were then blot-dried with sterile filter paper.

The sterilised common bean grains obtained from the different cultivars were then plated on potato dextrose agar media using the agar plate method [19]. The plating of the common bean grains was done at a rate of 10 bean grains per plate (Figure 4). The grains were spread evenly in the plates. A stock antibiotic solution comprising of $0.05 \mathrm{~g} / \mathrm{l}$ of streptomycin was added to the media to suppress bacterial growth [20]. The plates were covered by their lids and fastened using parafilm. The sealed plates were then maintained under incubation at $28 \pm 2{ }^{\circ} \mathrm{C}$ for 7 days to promote fungi growth [21].

\section{Morphological identification of fungi from stored common bean cultivars}

Identification of fungi isolates was done using macro-micro morphological characteristics. After 7 days of incubation, the plated common bean cultivars were observed for growth of fungi. Changes in the common bean nature such as colour and shape were noted. A small amount of fungal mycelium
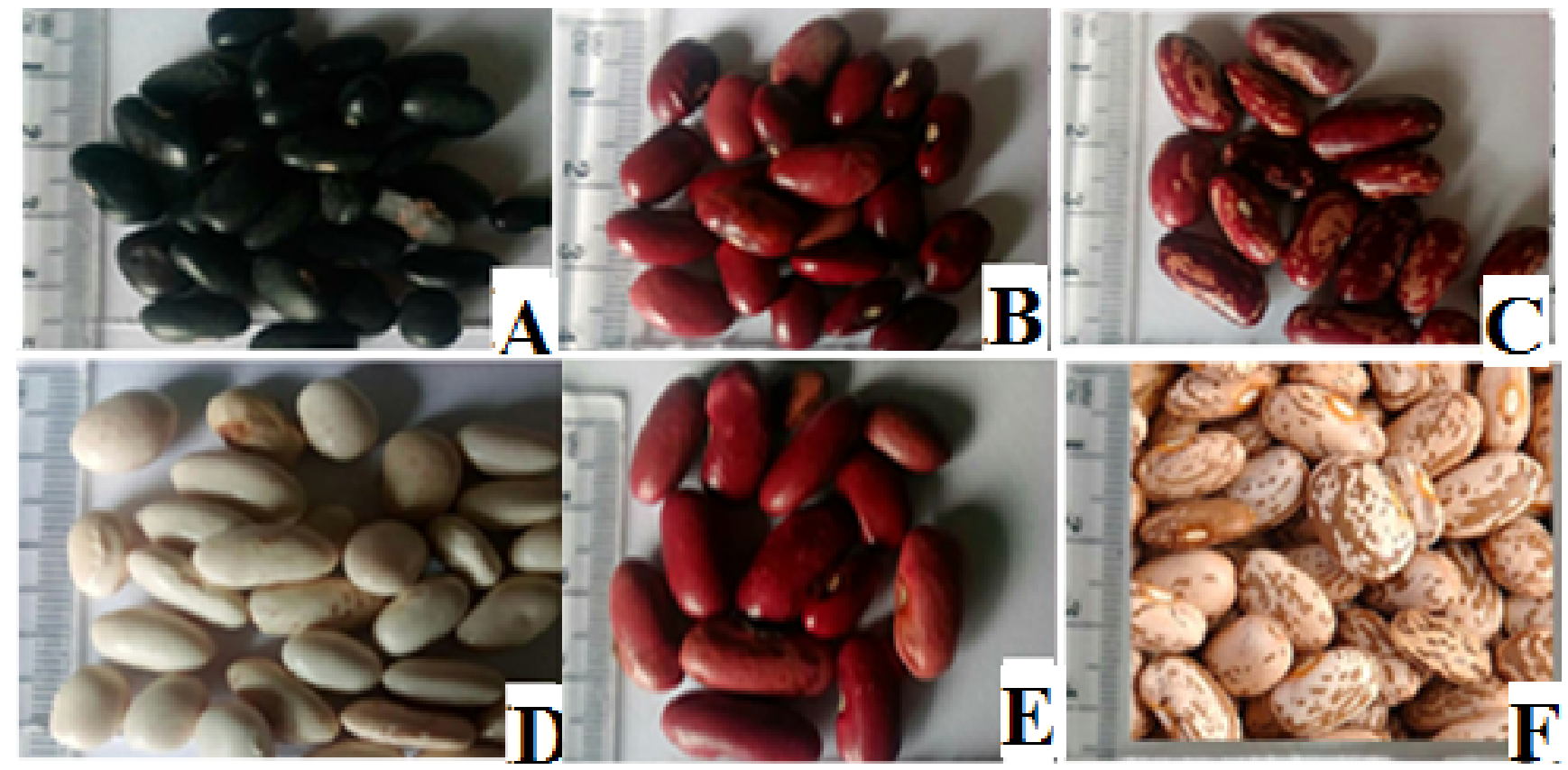

Figure 3: Cultivars of common bean collected from Menoua Division, Cameroon (a) Black turtle bean (Black bean); (b) Kidney bean (small sized red bean); (c) Pea bean (mottled red bean); (d) Navy bean (White bean); (e) Large seeded bean (Large red bean); (f) Pinto bean (mottled brown bean). 


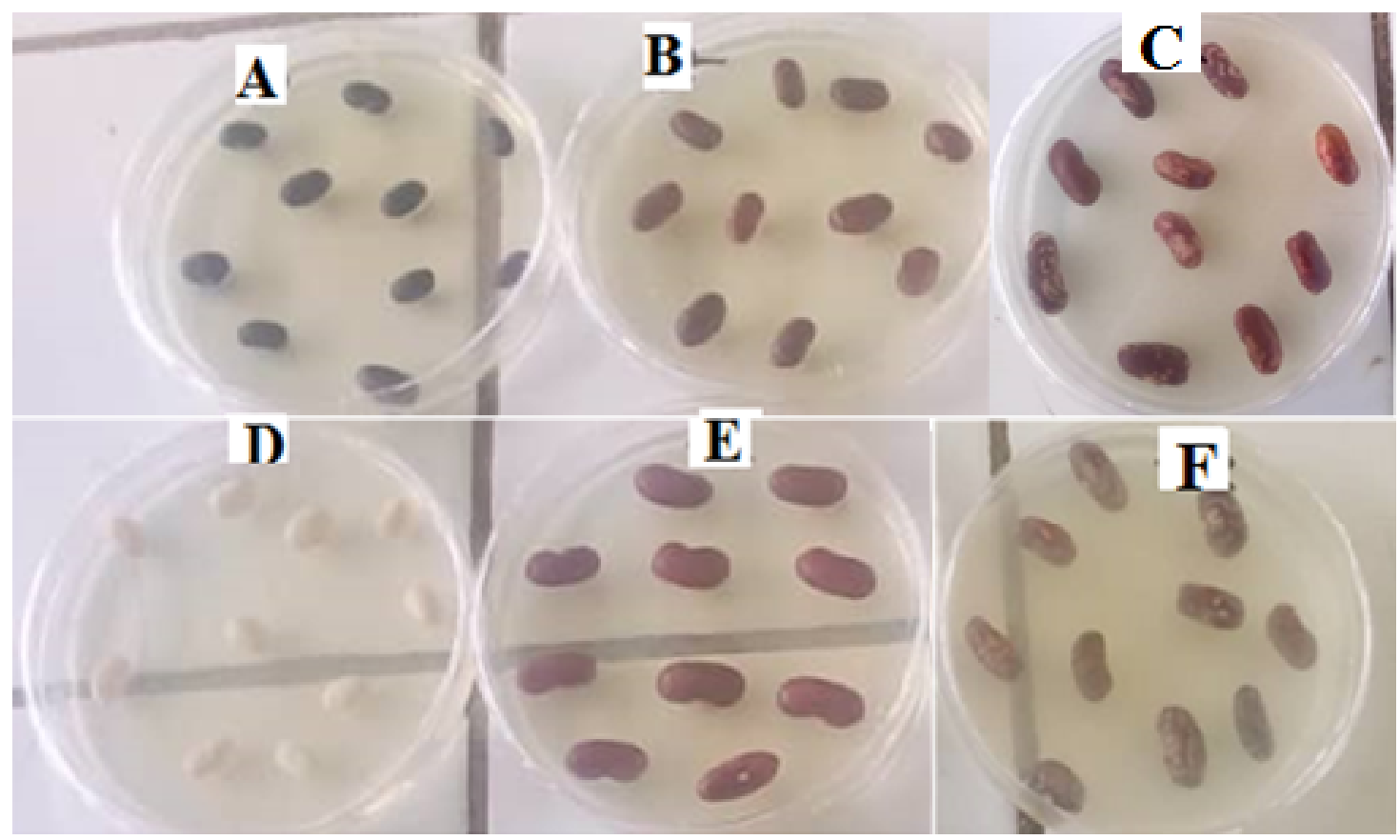

Figure 4: Common bean cultivars directly plated on PDA for isolation of fungi (a) Black turtle bean (Black bean); (b) Kidney bean (small sized red bean); (c) Pea bean (mottled red bean); (d) Navy bean (White bean); (e) Large seeded bean (Large red bean); (f) Pinto bean (mottled brown bean).

was transferred with the use of a sterile inoculating needle from the bean showing fungal growth onto a fresh PDA culture medium in a petri dish. This was sealed then incubated at $28 \pm 2{ }^{\circ} \mathrm{C}$ for 7 days to obtain pure cultures.

For microscopic observation, a small amount of mycelium collected from the different fungi colonies with the use of a sterilized inoculating needle was placed on clean microscopic slides. A drop of lactophenol blue was added on each slide. A cover slip was gently placed on the slides. The excess lactophenol on the slides was blotted out. The slide were then mounted on a microscope stage and visualized through the $x 10$ and $x 40$ objective of the lens for the presence of sporulation and reproductive structures.

Identification of Fungi was done based on macroscopic and microscopic characteristics and findings compared using established keys as described by Barnett and Hunter, et al. [22]. Fungi cultures that could not sporulate were classified as 'Mycelia sterilia' and sorted to Morphospecies based on cultural characteristics [23].

Cultural characteristics of the fungi in terms of growth, colony character, texture and sporulation on medium was noted. Colony characters of the different isolates were assessed on the media. Colony coloration was determined with the help of the Methuen handbook [24]. Grouping of the fungi isolates was done based on similarities in their morphological characteristics shown by their colonies.

\section{Determination of the population of fungi on common bean}

The population of fungi on common bean was established by counting the number of fungi colonies arising from each of the plated common bean grains. The total population of the colonies were recorded. The population of common bean infected with fungi was also determined by counting the number of common bean grains showing fungi growth or colonies.

\section{Statistical analysis}

Data on fungi population from replicates of the different plated common bean cultivars obtained were entered in a Microsoft Excel spread sheet and normality was determined. A One way ANOVA using SPSS version 20 statistical package was performed on the fungi population on the different common bean cultivars to determine whether the mean values of the cultivars were significantly different $(P \leq 0.05)$. The six different common bean cultivar types were categorised as groups ( 6 groups). Where means differed, means comparison using Tukey's test ( $\alpha=0.05$ ) was further performed to identify which means where significantly different.

A One-way ANOVA was also performed on the population of each fungal species present on each cultivar type. This was done to determine the susceptibility of a cultivar to particular species of fungi. Results were finally presented in tables and bar chart.

\section{Results}

\section{Population and diversity of fungi on stored com- mon bean cultivars}

Population of fungi on stored common bean cultivars: Fungal growth was exhibited on the plates of the different stored bean cultivars after a seven days period of incubation. This was noticeable by changes in the appearance of the cultivars such as color and fruiting bodies protruding from their 
Citation: Akwa TE, Maingi JM, Birgen J (2020) Susceptibility of Common Bean (Phaseolus Vulgaris L) Cultivars Grown in Menoua Division, West Region of Cameroon to Storage Fungi Pathogens. J Hortic Sci Res 3(1):94-103

Table 1: Fungi population on stored common bean cultivars in Menoua Division.

\begin{tabular}{|l|l|l|l|}
\hline Common bean cultivars & Number of plated bean grains & Number of bean grains infected & Number of fungi colonies \\
\hline Kidney bean & 50 & 15 & 17 \\
\hline Black bean & 50 & 12 & 13 \\
\hline Large seeded bean & 50 & 20 & 22 \\
\hline Pinto bean & 50 & 9 & 11 \\
\hline Pea bean & 50 & 10 & 11 \\
\hline Navy bean & 50 & 6 & 6 \\
\hline Total & 300 & 72 & 80 \\
\hline
\end{tabular}

Table 2: Mean population of fungi on stored common bean cultivars.

\begin{tabular}{|l|l|l|}
\hline Common bean Cultivars & N & $\begin{array}{l}\text { Mean population of fungi } \\
\text { on stored common bean } \\
\text { cultivars (colonies/plate) }\end{array}$ \\
\hline Red bean & 5 & $3.20 \pm 1.40^{\mathrm{b}}$ \\
\hline Black bean & 5 & $2.60 \pm 1.52^{\mathrm{b}}$ \\
\hline Large seeded red & 5 & $4.40 \pm 0.89^{\mathrm{a}}$ \\
\hline Pinto bean & 5 & $2.20 \pm 0.45^{\mathrm{c}}$ \\
\hline Pea bean & 5 & $2.20 \pm 1.30^{\mathrm{c}}$ \\
\hline Navy bean & 5 & $1.20 \pm 0.84^{\mathrm{c}}$ \\
\hline $\mathrm{P}=0.004(\mathrm{P}<0.05)$ & & \\
\hline
\end{tabular}

$\mathrm{N}=$ number of replicates. Values are expressed as means $\pm \mathrm{SE}$ for five replicates

a,b,c Means accompanied by different superscripts differ significantly at $\mathrm{P}<0.05$. surfaces. All of the different cultivar group types were shown to be infected by fungi. Some of the plated common bean grains also had more than one Fungal colonies growing from them. This could be seen by differences in the colony appearance such as colors on the surfaces of the bean grains. A total of 72 out of the 300 plated common bean grains were shown to be infected with fungi. A total of 80 fungal colonies resulted from the plated common bean grains (Table 1$)$. There was a significant difference $(P<0.05)$ in the mean population of fungi on the different cultivars at storage (Table 2).

From the results indicated, the mean population of fungi on stored common bean cultivars was shown to differ significantly from each other $(P<0.05)$. Highest fungal community was observed in large seeded cultivar having mean fungus level of $4.4 \pm 0.89$ (Table 2). Thus the large seeded bean cultivar was designated the most susceptible cultivar type to fungi infection. Lower fungal communities were observed in

Table 3: Morphological characterization and identification of isolated fungi from common bean cultivars.

\begin{tabular}{|l|l|}
\hline Fungi species & Macro and Micro characteristics \\
\hline Aspergillus spp & $\begin{array}{l}\text { Colony was fast growing and was yellow to dark on the surface and creamy yellow on the } \\
\text { reverse side. Microscopically, the conidiophores bore phialides on their entire surface. Globose } \\
\text { vesicles held on long conidiophores and smooth globose conidia. }\end{array}$ \\
\hline Morphospecies ('Mycelia sterilia') & $\begin{array}{l}\text { Colony mycelia white both on the surface and reverse. Colony with invisible conidia/spores on } \\
\text { stained septate mycelia. No fruiting bodies produced. }\end{array}$ \\
\hline Fusarium spp. & $\begin{array}{l}\text { Colony fluffy, pink red on the surface and light pink on the reverse. Curved microconidia } \\
\text { produced on simple, short phialides. Conidia had more than one cell. }\end{array}$ \\
\hline Penicillium spp. & $\begin{array}{l}\text { Colonies appeared green on the surface and creamy on the reverse. Conidia were borne in } \\
\text { unbranched chains, arising from bundles of cylindrical to bottle shaped, phialides closely } \\
\text { arranged in a brush-like head. }\end{array}$ \\
\hline
\end{tabular}

Table 4: Mean population of fungi isolates on stored common bean cultivars.

\begin{tabular}{|l|l|l|l|l|}
\hline \multirow{2}{*}{ Fungi/ Cultivar type } & \multicolumn{3}{l|}{ Mean population of isolate/ plate } & Penicilliumspp. \\
\cline { 2 - 5 } & Morphospecies & Aspergillusspp. & $0.20 \pm 0.20^{\mathrm{b}}$ & $0.20 \pm 0.20^{\mathrm{a}}$ \\
\hline Kidney bean & $2.80 \pm 0.20^{\mathrm{a}}$ & $0.20 \pm 0.20^{\mathrm{b}}$ & 0 & $0.20 \pm 0.20^{\mathrm{a}}$ \\
\hline Black bean & $2.00 \pm 0.20^{\mathrm{a}}$ & $0.40 \pm 0.20^{\mathrm{b}}$ & $1.00 \pm 0.40^{\mathrm{a}}$ & 0 \\
\hline Pinto bean & $1.20 \pm 0.40^{\mathrm{b}}$ & 0 & $0.40 \pm 0.20^{\mathrm{b}}$ & $0.20 \pm 0.20^{\mathrm{a}}$ \\
\hline Large seeded bean & $2.00 \pm 0.20^{\mathrm{a}}$ & $1.60 \pm 0.40^{\mathrm{a}}$ & $0.20 \pm 0.20^{\mathrm{b}}$ & 0 \\
\hline Pea bean & $1.00 \pm 0.40^{\mathrm{b}}$ & $1.00 \pm 0.40^{\mathrm{a}}$ & $0.20 \pm 0.20^{\mathrm{b}}$ & 0 \\
\hline Navy bean & $0.80 \pm 0.20^{\mathrm{b}}$ & $0.20 \pm 0.20^{\mathrm{b}}$ & & 0 \\
\hline
\end{tabular}

Values are expressed as means \pm SE for five replicates.

$a, b$ Means along respective columns accompanied by different superscripts differ significantly at $\mathrm{P}<0.05$. 


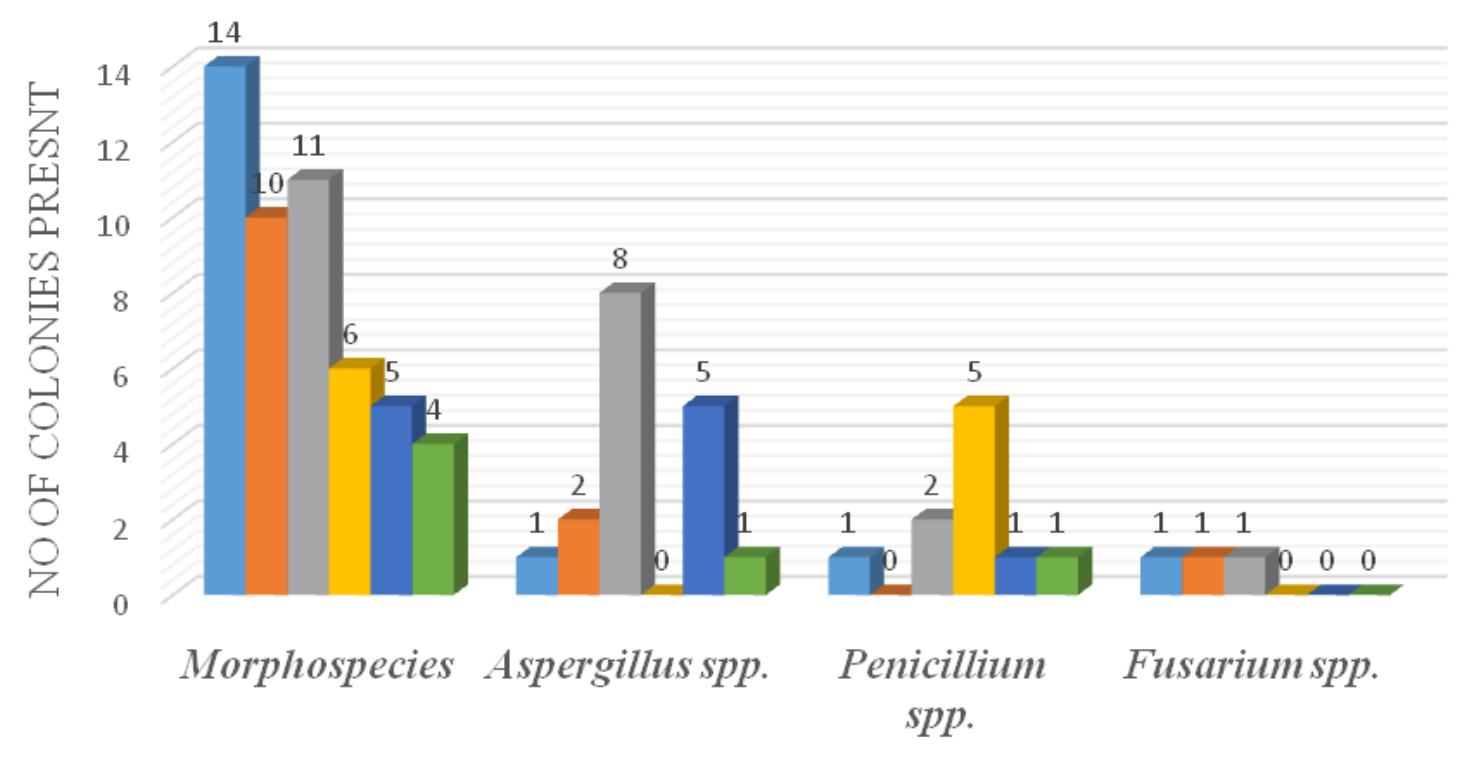

\section{FUNGI TYPE}

$\begin{array}{lll}\square \text { kidney bean } & \quad \text { Black bean } & \text { large seeded bean } \\ \square \text { Pinto bean } & \square \text { Pea bean } & \text { Navy bean }\end{array}$

Figure 5: Frequency of Occurrence of Fungi on stored common bean cultivars

Pinto bean cultivar, Pea bean cultivar and Navy bean cultivar with mean values of $2.20 \pm 0.45,2.20 \pm 1.30$ and $1.20 \pm 0.84$ respectively (Table 2 ). Based on these findings, these cultivars were identified as the least susceptible to fungi infection. There was no significant difference in the mean population of fungi on these cultivar types.

Diversity of fungi on stored common bean cultivars in menoua division: Based on the cultural and micro-morphological characteristics of fungi colonies, four distinct fungi isolate groups on the stored plated common beans were identified to be members of the genera Aspergillus, Penicillium, Fusarium and 'Mycelia sterilia' (Table 3).

The total frequency (population) of each fungi isolated from the replicates of stored common bean cultivars were obtained (Figure 5). Fusarium spp. showed no occurrence on stored pinto bean, stored pea bean and stored navy bean. Penicillium spp. showed no occurrence on stored black bean cultivar. Aspergillus spp. showed no occurrence on pinto bean. Morpho species was present on all the stored common bean type.

There was a significant difference $(P<0.05)$ between the mean population of each of the fungi isolated from the different stored bean cultivars (Table 4).

Occurrence of Morphospecies was higher on kidney bean, black bean and large seeded bean. This shows that the kidney bean, black bean and large seeded bean were most susceptible to the Morpho species as compared to the other cultivar types. Aspergillus spp. showed a higher occurrence on large seeded bean and pea bean. Thus, these cultivar types were more susceptible to Aspergillus spp. The occurrence of Aspergillus spp. on kidney bean, black bean and navy bean was not significantly different. The occurrence of Penicillium spp. was highest on the pinto bean. The pinto bean was thus the most susceptible to Penicilliumspp. There was no significant difference between its occurrence on the other bean cultivars. Fusarium spp. showed no significant difference in its occurrence on kidney bean, black bean and large seeded bean.

\section{Discussion}

In Menoua Division of Cameroon, common bean is a legume that is widely grown. Some farmers produce common bean in excess of what they need for food. The surplus is stored until the market prices are best then sold as a source of income that is desperately needed by the resource-poor rural farmers to improve their livelihoods. The quality of the bean at the time of selling depends on the duration of storage and the quality of the storage structures. The quality of the bean may progressively deteriorate over the storage period due to damage by rodents which may gain entry if the stores are not secure. For example the storage bag used by farmers in Menoua Division (Figure 1B) though well sealed, the sides are likely to be destroyed by rats because they are capable of biting and breaking the fibres used in making the bags and therefore gain access into the bag and consequently damage the beans as they feed on the grains thereby predisposing the grains to infection by fungi.

From the study, stored common bean cultivars were shown to be infected with fungi. Studies carried out by Kumari, et al. [25] on stored food grains in some regions in India demonstrated that the contamination of food grains by fungi 
Citation: Akwa TE, Maingi JM, Birgen J (2020) Susceptibility of Common Bean (Phaseolus Vulgaris L) Cultivars Grown in Menoua Division, West Region of Cameroon to Storage Fungi Pathogens. J Hortic Sci Res 3(1):94-103

increases with their duration of storage. Based on field analysis it was seen that farmers in the Menoua division of Cameroon stored their common bean cultivars after harvest in gunny bags and these bags are usually in direct contact with the floor surface which favors the development of moisture within the bean grains in the bag. Moisture is a major factor that contributes to the development of fungi in stored seeds [26]. Storage fungi exhibit rapid growth at temperatures between $25{ }^{\circ} \mathrm{C}$ to $32{ }^{\circ} \mathrm{C}$ [27]. This temperature range coincides with that of Menoua Division which therefore makes it favourable for the growth of these storage fungi. Studies by Golob, et al. [28] show that use of poor storage structures by farmers like polypropylene bags, granaries, above fire racks in the kitchen, plastic bags and other containers favors growth of mold as some of these structures do not protect common bean from picking up environmental moisture hence predisposing the stored bean to mold infection. The mode of transportation of food commodities from farms after harvest could also be a contributing factor to further contamination by fungi since most of the food commodities are not usually transported properly due to inadequate finances. Storage fungi on grains usually occur at low levels during pre-harvest but during post-harvest, they occur at relatively higher levels and show a wide distribution [29]. Fungal contaminants can spread even from minute amount of spores that settled on the grain from the field as it is taken to be stored. Fungal spores can also be transferred to grains either through handling, storage equipment or from spores that were already present in the storage structures. Under conditions of high temperature and moisture, the minute amount of inoculant can spread rapidly [30].

Lower fungal communities during storage were observed in Pinto, pea and white bean cultivars. These cultivars were designated the least susceptible to fungal infection. The lower colonization of these cultivars by fungi can be linked to the integrity of their seed coat which acts as a physical barrier to fungi invasion. Polyphenol oxidase, an enzyme responsible for the defense mechanism in plant has also been shown typically to be associated with the seed coat of Pinto beans [31]. Polyphenol oxidase activity localized in the seed coat has also been shown to play a major role in seed coat hardening which resist attack of seeds by pathogens. Hemagglutinins and defensins found in pinto beans have also been shown to demonstrate anti-fungal activities [32]. Similar research done in Laikipia, Kenya showed that the white bean cultivar was highly resistant to anthracnose; fungal disease of plant than other common bean cultivars [33]. This therefore shows that the incidence of fungi on bean cultivars also depends on the type of cultivar.

Highest fungal community was observed in large seeded cultivar and it was therefore designated the most susceptible to fungal infection. Reports indicate that the large size of bean seeds hinders the process of drying and storage as the seeds offer a low resistance to the flow of air. More time is therefore taken to move moisture from the inside to the outside of the seed. This creates a favorable environment or hotspot for the growth of fungi [34]. Similar research done in Uganda showed that resistance to Fusarium solani on common bean seeds has been associated with seed size. Small seeded common beans have been found to be more resistant to Fusarium solani than large seeded beans [35]. It has been reported that large-seeded red bean cultivar is the most cultivated and consumed common bean cultivar in Kenya [36]. Similar studies done in Kenya on common bean have proven that the large red seeded common bean cultivar is moderately resistant to the fungi disease, anthracnose [33].

The presence of resistant genes has also been shown to be a contributing factor to barriers of common bean cultivars to infection [37]. Fusarium solani that causes Fusarium rot has been reported to have a greatest impact on large-seeded bean cultivars as a result of lack of genetic resistance in these seed types [38].

\section{Conclusions and Recommendations}

This study is the first intensive survey on the susceptibility of common bean cultivars to fungi upon storage in the Menoua Division, West region of Cameroon. Common bean is a staple food and a major source of income to the resource-poor farmers. The nature of the storage structures used by farmers to store beans determines the preservation of the quality of the bean during the storage period. The most important agent of bean spoilage in the store is the presence of storage fungi. From the study, it was established that fungi of the genera Aspergillus, Penicillium, Fusarium and Morphospecies were responsible for the spoilage of the common bean grains in store. It was also observed in the study that differences exist among common bean cultivars in susceptibility to damage by fungi under storage environment by farmers in this region. The most susceptible common bean cultivar to fungal infection is the large seeded bean cultivar and the least are pinto bean cultivar, navy bean cultivar and Pea bean cultivar.

It is therefore recommended that pinto bean cultivar, navy bean cultivar and Pea bean cultivar be used for long term storage by farmers while the large seeded bean cultivar should be used for short storage duration.

\section{Acknowledgement}

The authors are thankful for the support provided by farmers of Menoua Division for the provision of common bean cultivars and also to the staff of plant pathology laboratory of the University of Buea for all laboratory assistance.

\section{Declarations}

\section{Ethical statement}

This article does not contain any studies with human participants or animals performed by any of the authors.

\section{Conflict of interest}

The authors declare that they have no conflict of interest.

\section{Consent for publication}

As Corresponding Author, I confirm that the manuscript has been read and approved for submission by all the named authors. 
Citation: Akwa TE, Maingi JM, Birgen J (2020) Susceptibility of Common Bean (Phaseolus Vulgaris L) Cultivars Grown in Menoua Division, West Region of Cameroon to Storage Fungi Pathogens. J Hortic Sci Res 3(1):94-103

\section{Funding}

No funding was obtained from any source.

\section{References}

1. Rangel AF, Mobin M, Rao IM, et al. (2005) Proton toxicity interferes with the screening of common bean (Phaseolus vulgaris $L$.) genotypes for aluminium resistance in nutrient solution. Journal of Plant Nutrition and Soil Science 168: 607-616.

2. Assefa T, Abebe G, Fininsa C, et al. (2005) Participatory bean breeding with women and small holder farmers in eastern Ethiopia. World Journal of Agricultural Sciences 1: 28-35.

3. FAOSTAT (2014) FAO Statistics online database. (Production/ crops - beans dry - year 2014) Food and Agriculture Organization.

4. Beebe SE, Rao IM, Mukankusi CM, et al. (2013) Improving resource use efficiency and reducing risk of common bean production in Africa, Latin America, and the Caribbean. International Center for Tropical Agriculture (CIAT), Cali, Colombia.

5. Kumar R, Mishra AK, Dubey N, et al. (2007) Evaluation of Chenopodium ambrosioides oil as a potential source of antifungal, antiaflatoxigenic and antioxidant activity. Int J Food Microbiol 115: $159-164$

6. Kamtchoum SM, Nuemsi PK, Tonfack LB, et al. (2018) Production of Bean (Phaseolus vulgaris L.) under organo-mineral fertilization in humid forest agro-ecological zone with bimodal rainfall pattern in Cameroon. Annual Research \& Review in Biology 29: 1-11.

7. Buruchara R, Chirwa R, Sperling L, et al. (2011) Development and delivery of bean varieties in Africa: the Pan-Africa Bean Research Alliance (PABRA) model. African Crop Science Journal 19: 227245.

8. Siri S, Ngantu H, Birachi E (2014) An overview of haricot bean production and trade volumes in Cameroon. International Journal of Development and Sustainability 3: 276-285.

9. Ngueguim M, Mekontchou T, Fobasso M, et al. (2011) Influence of time of planting on yield and grain quality of bean genotypes grown on an andosolin the western highlands of Cameroon. African Crop Science Journal 19: 247-254.

10. Tsague MK, Fotio AL, Bomgning CK, et al. (2019) Prevalence of viral and non-viral hepatitis in Menoua Division, West Region, Cameroon: A Retrospective hospital-based study. The Pan African Medical Journal 32: 212.

11. (2017) Annual statistics of the west region of Cameroon. Institut National de la Statistique (INS).

12. BUCREP (2010) 3eme RGPH: Rapport de présentation des résultats définitifs. BUCREP (Bureau Central des Recensements et des Etudes de la Population), Yaoundé.

13. Seino R, Dongmo T, Ghogomu R, et al. (2013) An inventory of short horn grasshoppers in the Menoua Division, West Region of Cameroon. Agriculture And Biology Journal of North America 4: 291-299.

14. Tankou C, Snoo GR, Persoon G, et al. (2017) Evaluation of smallholder farming systems in the Western Highlands of Cameroon. IOSR Journal of Engineering 7: 01-11.

15. Dongmo AL, ljang TP, Tuete A, et al. (2014) A situational analysis of agricultural production and marketing, and natural resources management systems in the humid tropical zones of Cameroon.

16. Kuehl RO (2000) Design of experiments: Statistical principles of research design and analysis. ( $2^{\text {nd }}$ edn), Pacific Grove (Calif.)
:Duxbury/Thomson Learning.

17. Yamane T (1967) Statistics: An introductory analysis. ( $2^{\text {nd }}$ edn), Harper \& Row, New York, Evanston \& London and John Weatherhill, Tokyo.

18. Schulz B, Wanke U, Draeger S, et al. (1993) Endophytes from herbaceous plants and shrubs: Effectiveness of surface sterilization methods. Mycological Research 97: 1447-1450.

19. Nega A (2014) Isolation and identification of fungal pathogens associated with cold storage type of (Coffee arabica) seed, at Jimma agricultural research center, Western Ethiopia. Journal of Biology and. Agricultural Healthcare 4: 20-26.

20. Vega FE, Posada F, Peterson SW, et al. (2006) Penicillium species endophytic in coffee plants and ochratoxin A production. Mycologia 98: 31-42.

21. Samson RA, Houbraken J, Thrane U, et al. (2010) Food and indoor fungi. ( $2^{\text {nd }}$ edn), Centraalbureau voor Schimmelcultures, Netherlands.

22. Barnett $H$, Hunter $B$ (1998) Illustrated genera of imperfect fungi. ( $4^{\text {th }}$ edn), The American Phytopathological Society, Minnesota, USA.

23. Lacap D, Hyde K, Liew E (2003) An evaluation of the fungal 'morphotype' concept based on ribosomal DNA sequences. Fungal Diversity 12: 53-66.

24. Kornerup A, Wanscher IH (1978) Methuen Handbook of Colour. $\left(1^{\text {st }}\right.$ edn), Eyre Methuen Ltd, London.

25. Kumari R, Jayachandran LE, Ghosh AK (2019) Investigation of diversity and dominance of fungal biota in stored wheat grains from governmental warehouses in West Bengal, India. Journal of the Science of Food and Agriculture 99: 3490-3500.

26. Magan N, Hope R, Cairns V, et al. (2003) Post-harvest fungal ecology: impact of fungal growth and mycotoxin accumulation in stored grain. In: Xu X, Bailey J A, Cooke B M (eds) Epidemiology of Mycotoxin Producing Fungi. Springer, Dordrecht.

27. Beckett SJ (2011) Insect and mite control by manipulating temperature and moisture before and during chemical-free storage. Journal of stored products research 47: 284-292.

28. Golob P (2009) On-farm post-harvest management of food grains: A Manual for extension workers with special reference to Africa. In: R A Boxall, Stephanie Gallat (eds), Agricultural and food engineering training and resource materials, Rome.

29. (2006) International Rice Research Institute (IRRI). Accessed 20 Nov 2014.

30. Kange AM, Cheruiyot EK, Ogendo JO, et al. (2015) Effect of sorghum (Sorghum bicolor L. Moench) grain conditions on occurrence of mycotoxin-producing fungi. Agriculture \& Food Security 4: 15.

31. Marles MA, Vandenberg A, Bett KE (2008) Polyphenol oxidase activity and differential accumulation of polyphenolics in seed coats of pinto bean (Phaseolus vulgaris L.) characterize postharvest color changes. J Agric Food Chem 56: 7049-7056.

32. Yin C, Wong JH, Ng TB (2015) Isolation of a hemagglutinin with potent antiproliferative activity and a large antifungal defensin from Phaseolus vulgaris cv. Hokkaido Large Pinto Beans. J Agric Food Chem 63: 5439-5448.

33. Wagara I, Kimani P (2007) Resistance of nutrient-rich bean varieties to major biotic constraints in Kenya. African Crop Science Conference Proceedings. 
Citation: Akwa TE, Maingi JM, Birgen J (2020) Susceptibility of Common Bean (Phaseolus Vulgaris L) Cultivars Grown in Menoua Division, West Region of Cameroon to Storage Fungi Pathogens. J Hortic Sci Res 3(1):94-103

34. Biddle A, Gent G, Knott C (1988) The PGRO pea growing handbook. Processors \& Growers Research Organisation, UK.

35. Clare MM, Melis R, Dereta J, et al. (2010) Identification of sources of resistance to Fusarium root rot among selected common bean lines in Uganda. Journal of Animal \& Plant Sciences 7: 876-891.

36. Korir M, Odhiambo M, Iruria D, et al. (2005) Bean Varietal preference in East African markets and its implications to breeding. African Crop Science Conference proceedings.
37. Singh SP (2001) Broadening the genetic base of common bean cultivars. Crop Science 41: 1659-1675.

38. Schneider KA, Grafton KF, Kelly JD (2001) QTL analysis of resistance to Fusarium root rot in bean. Crop Science 41: 535-542.

DOI: $10.36959 / 745 / 404$

Copyright: (C) 2020 Akwa TE, et al. This is an open-access article distributed under the terms of the Creative Commons Attribution License, which permits unrestricted use, distribution, and reproduction in any medium, provided the original author and source are credited. 